\title{
Waste Research at the IRNAS, CSIC
}

\section{R. LÓPEZ, F. CABRERA, J.M. MURULO and A. TRONCOSO - Instituto de Recursos Naturales y Agrobiología de Sevilla, CSIC Avda. Reina Mercedes s/n. Apdo. 1052. 41080 Sevilla}

The agricultural and livestock sectors are of great significance in the region of Andalusia (South of Spain) (Table 1). Important quantities of agricultural and agroindustrial residues are generated by these activities, frequently causing environmental problems. These residues contain organic matter and nutrients and could therefore be recycled and used as fertilizers or amendments, with or without a previous treatment (composting, concentration). For some of these wastes, recipes for compost mixes, such as olive oil wastewater based compost, have been developed by private companies. Afterwards, laboratory and field experiments have been conducted to study the best conditions for their agricultural use and their degradation process in the soil (González-Vila et al., 1992, Martín-Olmedo et al., 1994). In other cases, such as those of the vinasse based composts, both the compost fabrication and its use have been studied previously to the marketing stage (Díaz et al., 1993, Madejón et al., 1994). Our first research projects at IRNAS dealt with the properties and reuse of municipal solid waste (MSW), and are still in progress.

Table 1 Some figures showing the importance of the agricultural sector in Andalusia and Spain (Ministerio de Agricultura de España, 1993)

Final Agricultural Output (1991)

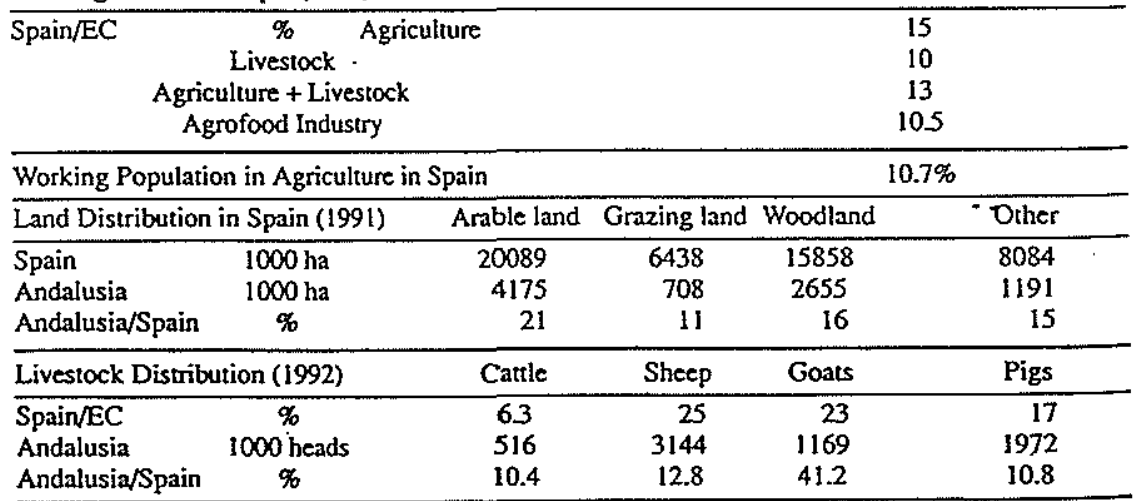


Table 2 shows a list of the most intensively studied wastes at the IRNAS. The topics covered for these wastes include the monitoring of the performance of various treatment systems (concentration, aerobic and anaerobic treatment), the study of the composting process and the study of land treatment or land utilization with treated and untreated wastes. In many of these studies, special attention has been paid to the interaction phenomena in the system waste-soil-plant-water. Some usual aspects studied in this context are shown in Figure 1.

Table 2 Some residues studied at the IRNAS

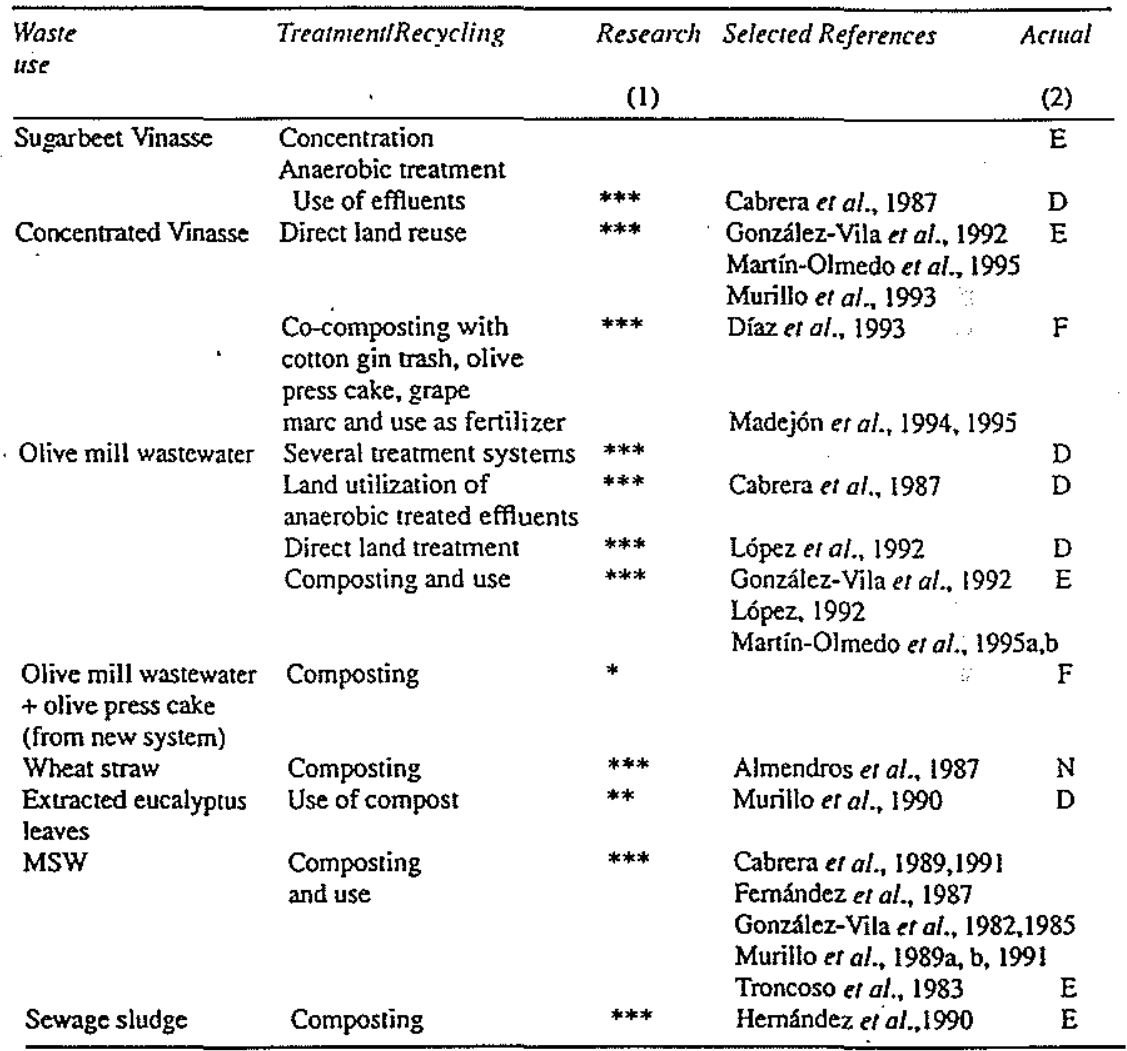

(1) * Starting; ** In progress; ***Advanced or finished

(2) N, without application; F, probable use in future; $D$, developed for use but not used or used in few cases; E, extensive use

\section{Municipal Solid Waste (MSW)}

Since 1965, several composting plants have been established in Sevilla and nearby cities. The Sevilla urban compost plant, the biggest in Andalusia, was closed some years ago, but now the Government is encouraging new plants for Sevilla (1300 ton day ${ }^{-1}$ of MSW) and other municipalities. Most of the compost produced in these 
plants is applied to the rice paddies in the Guadalquivir delta and to vineyards.

Some research projects on wastes in the IRNAS dealt with the properties and effects caused by MSW on soils and plants. Compost from the Sevilla composting plant was often employed in these studies which were focused on:

1. The characterization of the organic matter of the composts (González-Vila and Martín, 1985; González-Vila et al., 1982, Fründ et al., 1987; Almendros et al., 1987a,1991) and the fitting of techniques and analytical procedures.

2. The effects of the agricultural use of composts in the soil organic fractions, mainly the humic acids (González-Vila and Martín, 1987) and the soil lipids, which exercise a considerable influence on the physical and biochemical soil properties related to its fertility level (González-Vila et al., 1985).

3. The effects of the compost on the soil nutrient contents, such as phosphorus (Cabrera et al., 1991), potassium (Murillo et al., 1991) and heavy metals (Cabrera et al.,1989).

4. The effects on the soil physical properties (Fernández et al., 1987).

5. The response of various plant species to compost addition (Hemández, 1989; Hemández et al., 1992; Murillo et al., 1986, 1989a, b, c, 1995; Troncoso et al.,1983).

\section{Vinasse}

Vinasse (V) is the wastewater obtained from the distillation of alcohol after the alcoholic fermentation of sugarbeet molasses. Normal vinasse has high BOD (20-70 $\mathrm{g} \mathrm{L}^{-1}$ ) and high salt content (EC 25-30 dS m $\mathrm{m}^{-1}$ ) (Table 3). In Spain, ca. $10^{6} \mathrm{~m}^{3}$ per year of normal vinasse are produced.

Until a few years ago, sugarbeet vinasse was kept in evaporation ponds, which can cause pollution of ground water, a strong smell, appearance of insects and other nuisances. The first studies on vinasse at the IRNAS dealt with the pollution of wells surrounding the vinasse ponds. Following this investigation, sugar companies decided to treat vinasses.

Table 3 Characteristics of sugarbeet vinasses

\begin{tabular}{llll}
\hline & & Normal & Concentrated \\
\hline $\mathrm{pH}$ & & $4.3-5.0$ & $4.6-5.3$ \\
Dry matter & $\% \mathrm{w} / \mathrm{w}$ & $10.6-15.3$ & $25-63$ \\
Org. matter & $\% \mathrm{w} / \mathrm{w}$ & $7.4-11.1$ & $23-40$ \\
$\mathrm{~N}-\mathrm{Kjeldahl}$ & $\% \mathrm{w} / \mathrm{w}$ & 0.5 & $1.7-3.3$ \\
$\mathrm{P}\left(\mathrm{P}_{2} \mathrm{O}_{5}\right)$ & $\% \mathrm{w} / \mathrm{w}$ & 0.01 & 0.1 \\
$\mathrm{~K}\left(\mathrm{~K}_{2} \mathrm{O}\right)$ & $\% \mathrm{w} / \mathrm{w}$ & 0.7 & $2.2-4.6$ \\
$\mathrm{Ca}$ & $\% \mathrm{w} / \mathrm{w}$ & 0.25 & $0.3-1.0$ \\
$\mathrm{Mg}$ & $\% \mathrm{w} / \mathrm{w}$ & 0.16 & $0.3-0.7$ \\
$\mathrm{Na}$ & $\% \mathrm{w} / \mathrm{w}$ & 0.4 & $1.3-2.8$ \\
\hline
\end{tabular}

Plants for anaerobic treatment were designed and the effluents of these plants 
were used in fertirigation (Cabrera et al., 1987). These studies showed decreases in crop yields due to low P supply and salt accumulation in the soil treated with vinasse. A few factories installed systems for the anaerobic treatment but some others installed systems to produce concentrated vinasse which shows better properties for its recycling (Table 3). Concentrated vinasse (CV) is being used as fertilizer and for animal feeding, but the high salt content of the vinasse produced in the south of Spain limits use for a second time.

The experiments carried out with CV applied to several crops showed that moderate doses of $\mathrm{CV}\left(<9000 \mathrm{~kg} \mathrm{ha}^{-1}\right)$ did not cause any damage to germination and seedling performance (López, 1992; López et al., 1993; Murillo et al., 1993a). Concentrated vinasse (P supplemented) applied in deep fertilization produced yields similar to, or even higher than those obtained with mineral fertilizers (López, 1992, 1993; Murillo et al., 1993b). These yields are related to the high nitrogen mineralization rate of vinasse (López, 1992; Martín-Olmedo et al., 1995a).

Soils treated for 3 years with CV showed a moderate increase in their fertility levels (Lopez, 1992), particularly in organic- $\mathrm{N}$ which is slowly released over time (Martín-Olmedo et al., 1995a). No salt accumulation in treated soils was found after three consecutive years of application, despite the high salt content of vinasse.

No significant changes were observed in the humic fractions and lipid content of treated soils ( 2 years). However, analyses by GC-MS of the lipid compounds occurring in the subsoil layer in bound forms, revealed that some hydrophobic components had accumulated (González-Vila et al., 1992).

The concentrated vinasse is also being co-composted with other abundant byproducts produced in Andalusia, mainly to facilitate its incorporation into the soil, which presents some problems due to its high viscosity. The composting process was studied (Díaz et al., 1993) and the compost was employed in greenhouse and field trials with excellent results particularly in the fertilization of sugarbeet and cotton (Madejón et al., 1994, 1995). Some communications on this subject are presented at this Congress (see Madejón and Díaz).

\section{Olive oil mill wastewater}

The disposal of olive vegetation water (OWW) from olive processing industries is a problem in many Mediterranean countries for similar reasons to those mentioned above for vinasse: its high organic load (BOD 10-100 $\mathrm{g} \mathrm{L}^{-1}$, COD 40-200 $\mathrm{g} \mathrm{L}^{-1}$ ) and salt content (E.C. 8-22 $\mathrm{dS} \mathrm{m}^{-1}$ ).

Several treatment systems for OWW have been proposed or employed with different success. Cabrera (1995) reviewed the situation of OWW treatment in Spain.

The chemical characteristics of the OWW organic matter were studied by SáizJimenez et al. (1987) focusing on their lipidic fractions which contain non-stabilized hydrophobic constituents. 
In the case of OWW, recipes for compost mixes of the sludge obtained after dessiccation of the wastewater in ponds and other agricultural residues were developed by private companies. Such composts are welcomed by farmers. The phytotoxicity that OWW presents, due to its polyphenols, disappears with composting. So, composts of OWW do not inhibit the germination of plants such as cress or ryegrass (Cabrera et al., 1990) as OWW does.

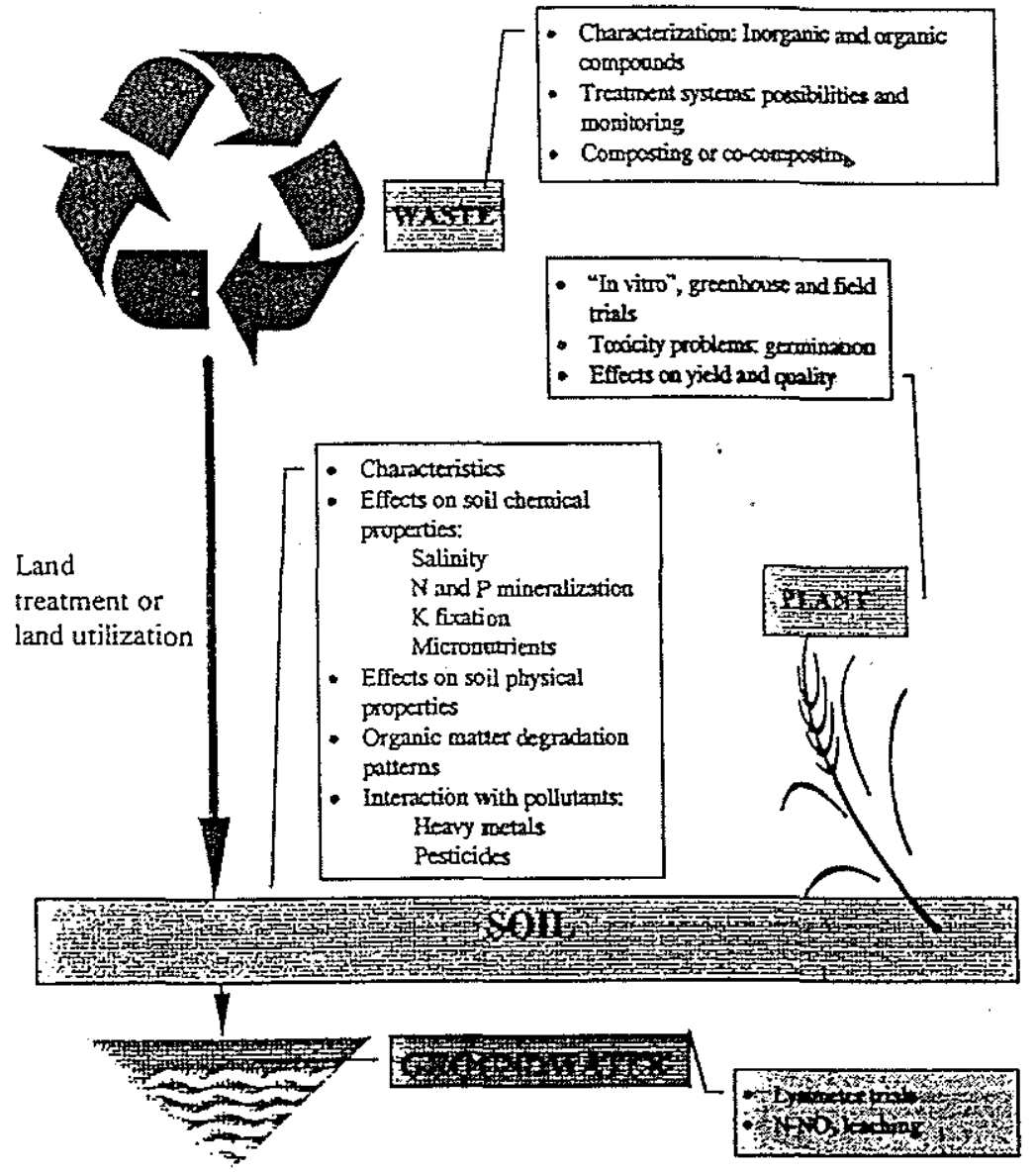

Figure 1 Interaction phenomena in the system waste-soil-plant-water

Succesive applications of composts have been proved advantageous fór the fertility status of soils, increasing their organic matter and N contents (López, 1992; Martín-Olmedo et al., 1995a, b) which are usually very low in semiarid regions.

The effect of composts upon the organic fraction of agricultural soils have also been studied by Gonzalez-Vila et al. (1992).

The application of OWW composts did not cause an imbalance in the nutritional status of ryegrass, barley, corn and sugarbeet. Although low $\mathrm{Mn}$ and $\mathrm{Zn}$ 
content were detected, they were above the sufficiency level (Cabrera et al., 1990; López, 1992).

Land treatment of OWW is an alternative disposal procedure, especially for small factories which can not afford more expensive treatment methods. For loading rates lower than $500 \mathrm{~L} \mathrm{~m}^{-2}$ year', in carbonate rich soils, no effects of the treatment up to $1 \mathrm{~m}$ soil layer were detected (López et al. 1992, 1995).

In water courses or soils, OWW forms soluble chelates with oligoelements and heavy metals, especially $\mathrm{Mn}$ and $\mathrm{Zn}$, facilitating their dissolution and mobility. The interaction between them and the composition and stability of the compounds formed have been intensively studied (Cabrera et al. 1984, 1986; Bejarano, 1995; Bejarano and Madrid, 1992; Madrid and Díaz-Barrientos, 1994a, b).

The enforcement of EC directives on wastes in addition to the great general preoccupation with the environment and the development of biological farming systems will enhance the use and research of wastes, and especially composts, in the South of Spain.

\section{References}

Almendros, G.; Fründ, R.; González-Vila, F.J.; Haider, K.M.; Knicker, H.; Lüdemann, H.D. (1991). Analysis of $13 \mathrm{C}$ and $15 \mathrm{~N}$ CPMAS NMR spectra of soil organic matter and composis, FEBS Letsers 282, 191-221.

Almendros, G.; Fründ, R.; González-Vila, FJ.; Lüdemann, H.D.; Martin, F. (1987a). NMR and ESR investigation of the humification processes in defined vegetable starting materials, $Z$. Pflanzenernähr. Bodenk. 150, 201-207.

A.mendros, G.; Martin, F.; González-Vila, FJ.; Martinez, A.T. (1987b). Biodegradación y compostaje de la paja de trigo inoculada con Ulocladium atrum. II. Degradación oxidativa de las sustancias hümicas del compost, Agrochimica 31, 438-456.

Bejarano, M. (1995). Interacciones de metales pesados con alpechín en el sistema agua-sedimentos. $\mathrm{Ph}$. D. Thesis. Universidad de Sevilla.

Bejarano, M.; Madrid, L. (1992). Solubilization of heavy metals from a river sediment by a residue from olive oil industry. Environ. Technol. 13, 979-985.

Cabrera, F. (1995). The problem of the olive oil wastes in Spain: treatment or recycling?, Biocycle (In press).

Cabrera, F.: Diaz, E.; Madrid, L. (1989) Effect of using urban compost as manure on soil contents of some nutrients and heavy metals. J. Food Agric. 47, 159-169.

Cabrera, F;; Lopez, R.; Murillo, J.M.; Breñas, M.A. (1990). Olive vegetation water residues composted with other agricultural by-products as organic fertilizer. Proc. 10th World Fertilizer Congress of CIEC. Welte, E. and Szabolcs, Y. eds. 475-483. Nicosia.

Cabrera, F; Moreno, F; Nacci, S.; de Arambari, P. (1987). Utilization of wastes from olive and sugarbeet processing industries in fertimigation. Proc. 4th Int. CIEC Symposium. Braunschweig. Vol. 1, 475-483. CIEC-FAL. Goettingen.

Cabrera, F.: Múrillo, J.M.; L6́pez, R.; Fiemández, I.M. (1991). Fate of phosphorus added with urban compost to a calcareous soil. J. Envir. Sci. Healsh B26, 83-97.

Cabrera, F: Soldevilla, M.; Osta, F; de Arambari, P. (1986). Interacción cobre-alpechines. Limnética 2,311-316.

Cabrera, F; Toca, C.G; Díaz, E; de Arambarri, P. (1984). Acid - water and agricultural pollution in a river skirting the Doñana National Park (Guadiamar river, South West Spain). Woter Res. 18, $1462-1482$.

Díaz, MJ.; Madejón, E.; Lopez, R.; Cabrera, F; Fernández, M.. (1993). Nitrificación en el proceso de co-compostaje de vinaza de remolacha Proc. IX Congreso Nacional de Quimica, Vol. 2, 167-172. Sevilla. 
Fernández, J.E.: Moreno. F.: Hernández, J.M.; Murillo, J.M. (1987) Influencia del apone continuado de residuos sólidos urbanos sobre propiedades físicas del suelo. Proc. $7^{\circ}$ Congreso Nacional de Química. Vol. 1, 195-199. Sevilla.

Fründ, R.; González-Vila. FJ.; Lüdemann, H.D.; Martin, F. (1987) Comparison of the solid state CPMAS and solution carbon-13-NMR spectra of humic acids extracted from composted municipal refuse, Z. Naturforsch. 42C. 205-208.

González-Vila, F.J.: Martin. F. (1985). Chemical structural characteristics of humic acids extracted from composted municipal refuse. Agriculture Ecosys. Environ., 14, 267-278.

González-Vila, F.J.; Martin, F. (1987). Modifications of the humic acid fraction in a soil treated with composted municipal refuse. Sci. Totol Emiron. 62, 459-466.

González-Vila, F.J.: Martin. F.: Verdejo. T. (1985). Changes in the lipidic fraction of soil resuluing from composted municipal refuse application, Agrochimica $29,210-219$.

González-Vila, F.J.: Sáiz-Jimenez. C; Martín. F. (1982). Identification of free organic chemicals found in composted municipal refuse, J. Emiron. Qual. 11, 251-254.

González-Vila, FJ.; Verdejo, T.; Martin, F. (1992). Characterization of wastes from olive and sugarbeet processing industries and effects of their application upon the organic fraction of agricultural soils, Intem. J. Environ. Anal. Chem. 46, 213-222.

Hemândez, J.M. (1989). Estudio de la Acción de Residuos Sólidos de la Ciudad de Sevilla (Compost Urbano) sobre el Suelo y Diversas Especies Vegetales. Ph. D. Thesis. Univ. de Sevilla.

Hemández. J.M., Murillo. J.M.: Cabrera, F. (1992). Lettuce (lactuca sativa L. cv. Romana Spring) response to urban compost fertilization. Agricoltura medirerranea $122,45-53$.

Hernández, M.T.: Moreno. J.I.: Costa, F.; Gonzälez-Vila, FJ.; Fründ, R. (1990). Structural features of humic acid like substances from sewage sludges, Soil Sci. 149; 63-68.

López, R. (1992). Efectos sobre el Suelo y los Cultivos de la Aplicación de Vinaza de Remolacha y Compost de Alpechín. Ph. D. Thesis. Univ. de Sevilla.

López, R.; Marínez-Bordiú, A.; Dupuy de Lôme, E.; Cabrera, F.; Murillo, J.M. (1992). Land treatment of liquid wastes from the olive oil industry. Fresenius Environ. Bull. 1, 129-134.

López, R.; Cabrera, F; Murillo, J.M. (1993). Effect of beet yinasse on radish seedling emergence and fresh weight production. Acta Horticulure 335, 115-1 19.

López, R.; Martínez-Bordiú, A.; Dupuy de Lôme, E.: Cabrera, F.; Sánchez, M.C. (1995). Soil properties after application of olive oil mill wastewater. Fresenius Emviron. Bull. (in press).

Madejón, E.; Diaz, M.J.; López, R., Lozano, C.; Cabrera, F. (1994). Cotton fertilization with mixtures of sugarbeet vinasse and agricultural residues. Presented at the VIII International CIEC Symposium, 91. Salamanca. Spain.

Madejon, E.; Diaz, M.J.; López, R., Murillo, J.M; Cabrera, F. (1995). Corn fertilization with three (sugarbeet) vinasse compost5. Fresenitis Emiron. Bull. 4 (4), (In press).

Madrid, L.; Diaz-Barrientos, E. (1994). Retention of heavy metals by soils in the presence of a residue from the olive-oil indusiry. Eur. J. Soil Sci. 45, 71-77.

Madrid, L.; Diaz-Barrientos, E. (1994). Nature of the action of olive mill wastewater on the mobility of heavy metals added to a soil. Fresenius Environ. Bull. 3, 226-231.

Martín-Olmedo, P.; López, R.; Cabrera, F.; Murillo, J.M. (1995a). Nitrogen mineralization in soils amended with organic by-products of olive and sugarbeet processing industries. Fresenius Emiron. Bull. 4, 59-64..

Martin-Olmedo, P.; Lopez, R.; Cabrera, F.; Murillo, J.M. (1995b). Residual effect of composted olive oil mill sludge on plant growth. Fresenius Emviron. Bull. (in press).

Ministerio de Agricultura de España (1993). The Spanish Agrofood Sector: Some Figures. MAPA. Madrid.

Murillo, J.M., Hernández, J.M., Barroso, M.; López, R. (1989c). Producción frente a contaminación en la utilización agricola de composts urbanos. Anales de Edafología y Agrobiología 48, 143-160.

Murillo, J.M.; Cabrera, F; Hemández, J.M.; Barroso, M. (1991). Influencia del aporte sucesivo de compost urbano sobre la disponibilidad de potasio de un suelo. Suelo y Plonta 1,653-662.

Murillo, J.M.; Cabrera, F; Lopez, R. (1993). Effect of beet vinasse on germination and seedling performance of ryegrass. J. Sci. Food Agric. 61, 155-160.

Murillo, J.M.; Cabrera, F; López, R. (1993). Influencia de vinaza de remolacha, concentrada y despotasificada, sobre la emergencia, producción de biomasa y contenido en nutrientes de ryegrass. Investigación Agraria: Producción y Protección Vegetales 8, $37-48$.

Murillo, J.M.; Cabrera, F; Lopez, R; Brun, P. (1990). Utilización como abono de composts derivados de hojas de eucalipto y onjo de uva. Actas I Cong. Int. de Quimica de la ANQUE. Vol. II, 
233-241. . Puerto de la Cruz Tenerife.

Murillo, J.M.: Cabrera, F; López, R.; Martín-Olmedo, P. (1994). Testing low-quality urban composts for agriculture: germination and seedling performance. Agr. Ecosys. Emiron. (in press).

Murillo, J.M.; Hemández, J.M.; Barroso, M.; Gómez, E. (1989b). Succesive applications of composted municipal refuse. II. Effect on selected plant characteristics. Agricoltura Mediterranea 119 , 236-245.

Murillo, J.M.; Hemández, J.M.; Barroso, M.; Troncoso, A. (1986). Algunos resultados obtenidos con la aplicación de residuos urbanos (Sevilla) a Lolium multiflorum Lam. cv. Barwoltra (Ryegrass de Westerwold). ITEA 6, 137-143.

Murillo, J.M.; Hermández, J.M.; Barroso, M.; Troncoso, A. (1989a). Successive applications of composted municipal refuse. 1. Effect on selected plant characteristics. Agricoltura Mediterranea 119 , 226-235.

Sáiz-Jiménez, C.; Leeuw, J.W.; Gómez-Alarcón, G. (1987). Sludge from the waste water of the oljve processing industry: a potential soil fertilizer?. Sci. Total Envir. 62, 445-452.

Troncoso, A.; Murillo, J.M.; Barroso, M. (1983). Influencia sobre el desarrollo y composición de lolium perenne L. de la fertilización con compost obtenido de residuos urbanos. Pasios 13 , $105-114$. 